San Jose State University

SJSU ScholarWorks

Master's Projects

Master's Theses and Graduate Research

Spring 5-2018

\title{
The Correlation between Enrollment Status and Graduation Rates of Master of Public Administration Programs
}

Jasmine Lorraine Ferrer

San Jose State University

Follow this and additional works at: https://scholarworks.sjsu.edu/etd_projects

Part of the Educational Assessment, Evaluation, and Research Commons, Higher Education

Commons, Other Public Affairs, Public Policy and Public Administration Commons, and the Public

Administration Commons

\section{Recommended Citation}

Ferrer, Jasmine Lorraine, "The Correlation between Enrollment Status and Graduation Rates of Master of Public Administration Programs" (2018). Master's Projects. 651.

DOI: https://doi.org/10.31979/etd.gvhy-jv9d

https://scholarworks.sjsu.edu/etd_projects/651

This Master's Project is brought to you for free and open access by the Master's Theses and Graduate Research at SJSU ScholarWorks. It has been accepted for inclusion in Master's Projects by an authorized administrator of SJSU ScholarWorks. For more information, please contact scholarworks@sjsu.edu. 
The Correlation between Enrollment Status and Graduation Rates of Master of Public $\underline{\text { Administration Programs }}$

by

Jasmine Lorraine Ferrer

A Thesis Quality Research Paper

Submitted in Partial Fulfillment of the

Requirements for the

Masters Degree

in

PUBLIC ADMINISTRATION

Prof. Frances Edwards. Ph.D.

Advisor

The Graduate School

San Jose State University

May 2018 


\section{Table of Contents}

INTRODUCTION 3

Statement of the Problem $\quad 3$

Research Question 3

BACKGROUND $\quad 4$

History of Accreditation $\quad 6$

Table 1: NASPAA Standards $\quad 8$

Graduation Rates $\quad 9$

$\begin{array}{ll}\text { Challenges and Opportunities within MPA Programs } & 10\end{array}$

Value of this Research $\quad 11$

LITERATURE REVIEW

$\begin{array}{ll}\text { Gap in Literature } & 12\end{array}$

$\begin{array}{ll}\text { Student Enrollment Status and Doctorate Degrees } & 14\end{array}$

$\begin{array}{ll}\text { METHODOLOGY } & 16\end{array}$

$\begin{array}{ll}\text { Methods Overview } & 16\end{array}$

$\begin{array}{ll}\text { Data Sources } & 16\end{array}$

$\begin{array}{ll}\text { Valid Responses } & 17\end{array}$

Table 2: NASPAA Research Variables 18

FINDINGS

Results $\quad 19$

Table 3: Demographic Characteristics by Institution Percentages of Part-Time Students 20

Table 4: Program Characteristics by Institution Percentages of Part-Time Students 20

Table 5: Graduation Completion Rates by Institution Percentages of Part-Time Students 21

Table 6: Graduation Rates by Variable 22

Graduated within 3 Years $\quad 22$

Graduated within 4 Years 23

Graduated within 5 Years $\quad 24$

Threats to Validity 25

$\begin{array}{ll}\text { ANALYSIS } & 27\end{array}$

$\begin{array}{ll}\text { SOURCES CONSULTED } & 31\end{array}$ 


\section{INTRODUCTION}

\section{Statement of the Problem}

The Network of Schools of Public Policy, Affairs and Administration (NASPAA) is an international association of universities and colleges that grant professional master's degrees in public policy, affairs and administration. In the academic year 2017-18 there were 301 member schools (NASPAA, 2017). NASPAA's mission is to advocate for quality education in the field of public service (Kellough, 2014). NASPAA promotes the global standard in public service education by ensuring the quality of master's degree programs in policy, administration, and public affairs of their member schools. This is evidenced by the association incorporating standards in their mission-based accreditation process (NASPAA, 2018a).

The Master's in Public Administration (MPA) degree program is designed to prepare students for a career in public service. Graduates of the program find careers in public sector management, healthcare, policy analysis, and in local, state and federal government organizations. NASPAA has noticed a decline in public service degree program applications and is concerned about retaining top-quality students to pursue careers in public service (Cheng, 2017).

\section{Research Question}

What is the correlation between part-time and full-time enrollment status and graduation rates for the MPA degree programs in NASPAA accredited schools? 


\section{BACKGROUND}

Educational institutions have developed into highly competitive environments (Bright, 2016). As a result, universities generally emphasize the values of affordability, access, retention, and success as they compete for the best students. Further, there has been a demand to investigate and understand the needs and expectations of prospective students, as well as the success of degree programs (Bright, 2016).

Bessett and Burton (2014) state that an individual's educational experience is vital to his or her career development. Individuals pursuing higher education have been shown to achieve economic, health and social benefits (Baume et al., 2013). Blumenstyk (2013) references President Barack Obama's 2012 campaign in which he commented on the importance of higher education to the economy. While it has been proven that education has a significant positive impact on society, the increasing cost of higher education creates barriers to entry. Two approaches to help alleviate the financial strain on students are to shorten degree completion time through incorporating a blend of online and in-class courses, and to assess not only enrollment rates but also graduation rates (Blumenstyk, 2013).

Higher education enrollments in master's, doctorate and professional degrees have been increasing (Hussar \& Bailey, 2013). The purpose of a master's degree is to equip students with specialized skills and advanced knowledge to become experts in a specific field of study (Bright, 2016). From 1997 to 2010, the total number of master's degrees awarded increased by 63 percent and is anticipated to increase by a further 34 percent by 2022 (Hussar \& Bailey, 2013). This demand is in response to the potential career advancements and salary increases that result from having a master's degree (U.S. Department of Education, 2007). In 2013, full-time workers over the age of 25 with a graduate degree earned $\$ 12,000$ more annually than their undergraduate degree counterparts. This salary difference does not include the factors of occupational 
qualifications, such as education or experience, however, the data provides a general comparison between the degrees (Torpey \& Terrel, 2015).

In order to make a decision on whether to pursue graduate school education, prospective students usually compare the tangible benefits, career advancements, and salary increases, against the degree's purpose and personal financial factors. These individuals evaluate the program's completion length and likely benefit in achieving his or her career goals (Torpey \& Terrell, 2015). Prospective students can anticipate completing a master's degree within two to three years as a full-time student, and about three to five years as a part-time student (United States Department of Education, 2007). Additionally, it is important for these individuals to financially plan for their graduate program. The National Center for Education Statistics (2013) reported that the average cost for a master's degree in 2013, including tuition and fees, was $\$ 16,435$ a year. It is advisable for individuals with financial constraints to explore available resources, such as state grants, employer tuition reimbursement and scholarships (United States Department of Education, 2007) to manage the financial commitment.

NASPAA accredited MPA degree programs have the common goal, which is to educate students for careers in the public sector (NASPAA, 2018d). Based on the institution, MPA programs can reside in various departments, such as political science, health, social work, business, law and criminal justice (Bright, 2016). Each institution has different MPA program admission requirements, which include grade point average (GPA), graduate record examinations (GRE), letter of intent, letter of recommendation and course pre-requisites (Cheng, 2017). Likewise, the definition of a part-time or full-time student differs from one institution to another. The most common definition of a part-time graduate student is one who is enrolled in 8 
units or less, and a full-time graduate student is one who is enrolled in 9 units or more (CSU, n.d).

\section{History of Accreditation}

Sylvia and Sylvia (2012) state that organizations have clear standards to illustrate their structure and support for the achievement of their mission. Standards are defined as the criteria by which an organization's operations and services can be judged. Criteria can be categorized as industry standards, or comparative, historical, or engineered standards; however, standards can incorporate a combination of these categories based on the services being evaluated and the clientele (Sylvia and Sylvia, 2012).

Standards can promote the organization's transparency and accountability. The legislature and politically appointed administrators set efficiency standards for public organizations, while professional associations also enforce external standards. As a result, professionals working in these fields focus on the following: adhere to qualification standards, ensure that treatment modalities are aligned with professional practices for their respective disciplines and that services are beneficial to the populations the organization is serving. Overall, the purpose of the standards used by an organization is to ensure that there is a consistent implementation of services by well-qualified providers (Sylvia \& Sylvia, 2012).

Professional associations develop and maintain processes pertaining to accreditation standards. According to the United States Department of Education (n.d.), the purpose of accreditation is to verify that higher education institutions are providing adequate quality levels of instruction to their students. The educational accreditation process in the United States involves federal and state government agencies and non-government agencies. The primary functions of accreditation are to evaluate the quality of academic programs, develop a culture of 
continuous improvements regarding academic quality, to promote the standards in the institution, involve staff and faculty in the process, and to develop measures for professional licensure and certification (United States Department of Education, n.d.).

There are two types of educational accreditation: institutional and specialized. Institutional accreditation pertains to the entire higher education institution, whereas specialized accreditation, or programmatic accreditation applies to the individual programs, departments or schools of an institution (U.S. Department of Education, n.d.). Accreditation is granted for a specific duration, and upon expiration, the institution or program will need to go through a review process. However, it has become more common for institutions and programs to incorporate assessments and evaluations prior to accreditation reviews to prevent accreditation loss (Sylvia \& Sylvia, 2012).

An example of a specialized educational accreditation is the entity that provides accreditation for MPA degrees, NASPAA's Commission on Peer Review and Accreditation (COPRA). NASPAA originated in 1970 as the accrediting arm of the American Society for Public Administration and currently provides a global standard for programs in public service education (NASPAA, n.d.). In its early stages, NASPAA was an avenue for MPA administrators to collaborate on the topics of faculty, course content, and overall program autonomy and delivery. As the association progressed, NASPAA sought ways to promote the quality of its programs and developed COPRA. COPRA then created standards for programs to assess themselves against (Sylvia \& Sylvia, 2012). Additionally, COPRA is recognized as the global accreditor of MPA programs by the Council for Higher Education Accreditation (CHEA). In 1986, NASPAA became the accrediting entity of the Council on Postsecondary Accreditation (COPA) for MPA programs, and developed standards that were adopted in 2009 and amended in 
2014 (NASPAA, 2014). These standards currently set compliance guidelines for programs seeking reaccreditation or beginning the accreditation process (NASPAA, 2018b). The standards are listed below in Table 1.

\section{Table 1: NASPAA Standards}

\begin{tabular}{|l|l|}
\hline Standard 1 & Strategically Managing the Program \\
\hline Standard 2 & Matching Governance with the Mission \\
\hline Standard 3 & Matching Operations with the Mission: Faculty Performance \\
\hline Standard 4 & Matching Operations with the Mission: Serving Students \\
\hline Standard 5 & Matching Operations with the Mission: Student Learning \\
\hline Standard 6 & Matching Resources with the Mission \\
\hline Standard 7 & Matching Communications with the Mission \\
\hline
\end{tabular}

Source: NASPAA, $2018 b$.

Similar to the definition of standards previously mentioned, the standards of NASPAA offer transparency and accountability to the association and ensure consistent quality within MPA programs in accredited institutions. Each standard provides sub-points for clarification as well as a rationale statement that states how it is aligned with its mission, vision, objectives, and resources as applicable (NASPAA, 2014).

The standard that is most associated with graduation rates is number 4 , matching operations with the mission: serving students. This standard states that the program's mission, process, and outcomes are connected to how the program recruits, admits and supports their students. One of the most critical outcomes of MPA programs is graduation rates. As a result, this standard states that it is important for programs to have adequate support systems inside and outside of the classroom for matriculated students. Examples of support systems include skilled 
faculty and lesson plans, advising sessions and internship and job placements. In turn, MPA students learn skills that can be transferred to their future careers, and receive guidance throughout their academic career towards graduation (NASPAA 2018d).

\section{Graduation Rates}

Prior to the academic year 2017-18, NASPAA categorized graduation rates based on the benchmarks of three years, four years and five years. In an effort to align these benchmarks with how institutions actually report graduation rates, COPRA has amended the benchmarks for the academic year 2017-18; they will now reflect benchmarks of two, three and four years.

Additionally, institutions can report on students that graduate from the program after four years (NASPAA, 2018d).

As previously stated, students typically complete a graduate program in two to five years. However, graduate programs in the United States may allow graduate students to complete their programs in up to seven years. This time limit policy for program completion is evidenced in the universities in the state of California, Eastern Kentucky University (EKU, 2018), University of Oregon (UO, 2018), University of Illinois (Illinois Graduate College, 2018), University of Connecticut (UCONN, 2018), and University of Alabama (UA, 2018). According to the California Code of Regulations (The Master's Degree, 5 CCR §40510), the maximum number of years for a candidate for a master's degree to complete program requirements is seven years. Extensions may be permitted based on the California institution, with the expectation that the outdated courses are validated. The California Code of Regulations further states that in order for a candidate to complete the master's degree program, he or she is required have a 3.0 GPA, and to satisfactorily complete a comprehensive examination, thesis or project that evidences the 
student's critical and independent thinking and mastery of the subject matter (The Master's Degree, 5 CCR §40510).

\section{Challenges and Opportunities within MPA Programs}

While investigating graduation rates, it is also important to understand the characteristics of MPA programs. Pautz and Neeley (2017) state that small program sizes are the norm for most MPA programs in the United States and that these programs have certain opportunities and challenges. This article defines a small program as a program having less than one hundred students (NASPAA, 2016). However, this is not to dismiss the challenges and difficulties caused by internal and external factors of MPA programs of other larger sizes.

The seven main challenges that the authors identified are explaining the value of the program to the university's community, having limited advocates for the program, enhancing the value of the MPA graduate program in an institution that promotes undergraduate education, capitalizing on the institution's undergraduate focus to create a pipeline for graduate students, collaborating with both undergraduate and graduate disciplines, recruiting prospective students and retaining bright students, and responding to external regional factors in the public sector. These specific challenges are in addition to the common concerns of faculty staffing and financial resources (Pautz and Neeley, 2017).

In response to these challenges, Pautz and Neeley (2017) offer suggestions for improvement for MPA programs facing similar situations. These opportunities consist of leveraging opportunities to educate program stakeholders on the value of the MPA program and degree, to partner with other disciplines in the institution, to consider each student's unique academic situation, and to encourage alumni engagement. Also, having limited advocates for the 
program allows for the advantage of faster decision making processes, because there is no need to acquire consent from a large team (Pautz and Neeley, 2017).

It is important to delineate the challenges that smaller MPA programs face because most MPA programs in the United States fall into this category. Further, these are variables that could influence graduation rates and do not necessarily affect enrollment status (whether students attend full time or part time). Lastly, it is beneficial to understand that the authors used a multistep process to assess these seven challenges to then enabled them to provide solutions to bridge the gaps within MPA programs (Pautz and Neeley, 2017).

\section{Value of this Research}

This research into the possible influence of full time or part time status on graduation rates is valuable because it provides useful information about graduation outcomes to the stakeholders of MPA programs. The findings will be significant to the following stakeholders: NASPAA accredited schools, directors and faculty of the MPA program, and prospective and current students of the MPA program. 


\section{LITERATURE REVIEW}

\section{Gap in Literature}

The researcher acknowledges that there is a lack of literature pertaining specifically to student enrollment statuses and MPA degree programs, as well as student enrollment status and master's degree programs in general. This study is worthwhile because it has responded to this gap in the literature. In order to understand the impact of enrollment status and degree attainment, this section provides insight into the qualities of graduate students and graduate programs.

\section{Characteristics of Graduate Students}

Students enrolling in graduate programs exhibit self-determination to master a specific subject matter (Hegarty, 2011). Hegarty (2011) states that enrolling in a graduate program is an intimidating process in comparison to that of a professional certificate or continuing education credits. This is a result of the decision-making process that graduate students go through and the attitude they have in regards to the time commitment to attain a degree. Individuals pursue higher education due to intrinsic and extrinsic motivations associated with graduate degrees. Intrinsic motivation is the student's genuine passion for the subject matter and the desire to learn more about the field of study. Extrinsic motivation is the student's tangible goals that will be achieved in the program. This could include monetary rewards or job placements (Hegarty, 2011).

Mullen et al., (2003) conducted a study to better understand the demographic characteristics of graduate students. Graduate students who were older than 30 were typically from low socioeconomic backgrounds and completed the program at a slower rate than younger students (Mullen et al., 2003). Also, students are indirectly influenced by their parents' academic achievements to pursue higher education (Mullen et al., 2003). Students whose parents had a 
graduate degree were likely to enroll into a graduate program, excel in the program and to obtain a degree (Mullen et al., 2003).

Additionally, Girves and Wemmerus (1988) conducted a regression analysis that identified full-time graduate students as having higher graduation completion rates than part-time graduate students. It was concluded that full-time students had more incentives to obtain a master's degree and fewer distractions from external factors, such as employment, families or financial responsibilities (Girves \& Wemmerus, 1988).

\section{Characteristics of Graduate Programs}

It is important to consider the characteristics of graduate programs when investigating degree attainment. Smaller cohorts positively impacted degree attainment due to an increase in interactions between graduate students and faculty. This communication is an essential distinction between undergraduate programs and graduate programs. Unlike undergraduate programs, the faculty in graduate programs is responsible for more than advising on course requirements. They are responsible for providing their students with motivation, networking opportunities and constant feedback. Faculty in graduate programs offered guidance and support for the student academically and professionally (Girves \& Wemmerus, 1988).

In order for graduate programs to be successful, Hegarty (2011) found that it was important for institutions to be aware of different learning styles among graduate students. This is valuable for the faculty and program coordinators because it allows them to best meet the needs of its students. For instance, it was beneficial for faculty to understand that some students needed group exercises to learn the skills of problem solving and that others benefited from hearing experiences in the workplace from peers to understand a topic. Additionally, graduate students that attended classes during the day had different qualities than those who were enrolled 
in the evening or online classes. Those who attended classes during the day were likely to be full-time graduate students and had similarities in ethnicity and motivations. Conversely, those enrolled in evening or weekend classes were likely to be part-time students and from a variety of ethnic backgrounds (Hegarty, 2011). Graduate programs need to be aware of their student populations in order for their faculty to better serve them. Students who felt supported and respected by their professors were on track for graduation. These are important elements for the students to persist through the program and ultimately complete the degree (Girves \& Wemmerus, 1988).

Factors that can negatively impact a student's persistence and degree attainment include financial constraints and career advancements. Financial obligations and unforeseen costs can cause the student to discontinue the program. Career advancements can also decrease the motivation and academic progress because of the opportunity for jobs and financial security (Girves \& Wemmerus, 1988). This could offer possible reasons as to why graduate students do not complete the MPA program.

\section{Student Enrollment Status and Doctorate Degrees}

Gardner and Gopaul (2012) conducted a study on the experiences of part-time and fulltime doctoral students of varying degree programs. The authors stated that full-time doctorate students may adopt the habits, skills, and attitudes necessary to obtain a doctorate degree. Further, these students have the time to concentrate solely on the program's research requirements which leads to increased graduation rates. Interestingly, the study found that the characteristics of part-time doctoral students varied depending on the student's field of study. This is due to the culture and nature of the program. For instance, there is a large population of 
part-time students in the education and social work fields, in comparison to other disciplines (Gardner \& Gopaul, 2012).

Since full-time students have more time to focus on the doctorate program's requirements, it is perceived that part-time doctorate students are less engaged and committed to the program. However, the study found that the part-time doctorate population had barriers to degree completion, such as financial constraints, schedule conflicts, personal obligations and lack of support. The authors found that both part-time and full-time doctorate students had a difficult time balancing the program with external responsibilities, but that part-time students felt significantly more pressure to balance their obligations than the full-time students. The part-time doctorate students in this study either worked full-time, were parents and/or a single parent. They expressed that during their academic career they have made sacrifices to maintain the balance of the constraints noted, and mentioned that they felt discouraged at the amount of time they could dedicate to their studies in comparison to their full-time counterparts. In response to these concerns for the part-time doctoral student population, the authors suggest that doctoral programs provide on-campus counseling, childcare, and writing resources, and for specialized disciplines to offer academic career path planning workshops. These recommendations were made in an effort to retain part-time doctoral students and increase completion rates (Gardner \& Gopaul, 2012). It is likely that similar differences exist among part-time and full-time master's level graduate students, as well. 


\section{METHODOLOGY}

\section{Methods Overview}

This research study used descriptive analysis to assess the relationship between student enrollment statuses and graduation rates of MPA programs of NASPAA accredited schools. The forecasting methods of correlation and regression analysis were used to evaluate the relationship between these variables. These quantitative research methods provided a statistical evaluation of past data to examine the significance of the relationships (Sylvia \& Sylvia, 2012). The data acquired for this study were analyzed using the Statistical Package for the Social Sciences software (IBM SPSS, 24).

\section{Data Sources}

This research study used survey data acquired from NASPAA's public data center. In 2010, NASPAA started gathering data on an annual basis to identify the major outcomes and outputs of nationally and internationally accredited programs. NASPAA collected this data through accreditation maintenance reports, self-study reports and annual program surveys (NASPAA, 2018c).

The research compiled and assessed the raw data available for the academic years 20102016 and determined that the academic years 2014-15 and 2015-16 had the most valuable data to guide the research process to answer the research question: What is the correlation between parttime and full-time enrollment status and graduation rates of MPA degree programs at NASPAA accredited schools? The academic years 2014-15 and 2015-16 were selected because of the stabilization of the data collection methodology by NASPAA.

Data pertaining to international programs and accredited NASPAA programs that were not categorized as MPA programs were excluded for the sake of conceptual parsimony. As such, 
the findings of this study only applies to NASPAA accredited schools with MPA programs in the United States.

Table 2 presents the descriptive statistics for the variables for this study. As illustrated below, the dependent variable is graduation rates of MPA students within a given MPA program, which is separately measured as graduation within three, four and five years of commencing classwork.

The independent variable is the program's enrollment status, and the control variables consist of gender, the size of the program, ethnicity, evening classes and weekend classes. Gender is measured by the percentage of female students enrolled in the program and ethnicity is measured by the percentage of students identifying as a non-white ethnic group. The control variables size of the program, weekend classes, and evening classes are dummy variables. The size of the program is defined as 0 meaning small and 1 meaning large. A small MPA program is one with ninety-nine students or less, while a large program is defined as one with one hundred or more students. The variables of weekend classes and evening classes is defined as 0 meaning no and 1 meaning yes. While the focus of this research pertains to enrollment status and graduation rates, it was important to include additional control variables in order to understand the variance of graduation rates in the sample.

\section{Valid Responses}

A total of 154 accredited schools with MPA programs provided responses to NASPAA for the academic years 2014-15 and 2015-16. Therefore, a total of 308 responses were gathered for this study. Of those 308 responses, Table 2 displays the number of valid responses per variable in the column labeled Number of Institution Responses. 
Table 2 shows that in the academic years 2014-2016, the MPA programs within the United States had approximately $49 \%$ of their students enrolled in part-time status, and that the average percentage of graduation increased as the length of time to completion increased. At three years, the average student graduation rate was 50\%, at four years it was $68 \%$ and at five years it was $75 \%$. The demographic characteristics of this sample show that about $58 \%$ of students were female and about $36 \%$ were ethnic minority students. In regards to the MPA program characteristics, $46 \%$ were large programs, $41 \%$ had weekend classes and $97 \%$ had evening classes.

\section{Table 2: NASPAA Research Variables}

\begin{tabular}{clcccc}
$\begin{array}{c}\text { Number of } \\
\text { Institution } \\
\text { Responses }\end{array}$ & \multicolumn{1}{c}{ Variables } & $\begin{array}{c}\text { Minimum } \\
\text { Response }\end{array}$ & $\begin{array}{c}\text { Maximum } \\
\text { Response }\end{array}$ & $\begin{array}{c}\text { Average } \\
\text { Response }\end{array}$ & $\begin{array}{c}\text { Standard } \\
\text { Deviation }\end{array}$ \\
\hline 276 & \%Graduated within 3 years & 0 & 100 & 50.07 & 23.13 \\
277 & \%Graduated within 4 years & 9 & 100 & 68.41 & 19.72 \\
277 & \%Graduated within 5 years & 21 & 100 & 75.87 & 17.96 \\
& & & & & \\
232 & \%Part Time & 0 & 100 & 49.13 & 26.21 \\
259 & \%Female & 13 & 90 & 58.18 & 10.56 \\
256 & \%Ethnic Minorities & 0 & 100 & 35.93 & 22.39 \\
242 & Size of Program (Dummy) & 0 & 1 & 0.46 & 0.49 \\
282 & Offers Weekend Classes (Dummy) & 0 & 1 & 0.41 & 0.49 \\
282 & Offers Evening Classes (Dummy) & 0 & 1 & 0.97 & 0.16 \\
\hline \hline
\end{tabular}




\section{FINDINGS}

The purpose of this research was to determine whether there was a positive or negative correlation between enrollment status (part-time or full-time) and graduation rates. This section presents cross-tabulations and regression models to illustrate the relationships between enrollment statuses and demographic characteristics, program characteristics and graduation rates.

\section{Results}

The percentage of students enrolled in a part-time status was divided into four groups: schools, where less than $25 \%$ of students were enrolled at part-time, where $25-49 \%$ of students were enrolled part-time, where $50-74 \%$ of students were enrolled part-time, and where more than $75 \%$ of students were enrolled part-time. Dividing the percentage of part-time students in this way allowed the research to better evaluate the graduation persistence of part-time students from this sample.

Table 3 displays the demographic characteristics, gender and ethnicity of part-time students. Institutions that had $50-74 \%$ of students enrolled at part-time had the highest percentage of female and ethnic minority students; this group had 79\% female students and 78\% ethnic minority students. In contrast, institutions that had $75 \%$ or more students enrolled at parttime had the lowest percentage of female and ethnic minority students. This group had $46 \%$ female students and 44\% ethnic minority students. Institutions where students were enrolled less than $50 \%$ part-time show that females and ethnic students were consistently reported at $53 \%$. There are clear differences between the demographic characteristics among the part-time students. As the institution's part-time status increased, the demographic characteristics fluctuated. 
Table 3: Demographic Characteristics by Institution Percentages of Part-Time Students

0-24\% Part-Time 25-49\% Part-Time 50-74\% Part-Time 75-100\% Part-Time

\begin{tabular}{cc}
$\%$ Female & $\%$ Ethnic Minorities \\
\hline $53 \%$ & $53 \%$ \\
$53 \%$ & $53 \%$ \\
$79 \%$ & $78 \%$ \\
$46 \%$ & $44 \%$ \\
\hline
\end{tabular}

Table 4 illustrates the program characteristics of the part-time groups. These characteristics consisted of the MPA program's size, availability of evening classes and availability of weekend classes. The findings show that most institutions in this sample had small programs, with the exception of having 41 large programs in institutions that had $50-74 \%$ of part-time students. This is evidenced by 0-5 institutions reporting to not have evening classes, while 38-76 reported offering weekend classes. Throughout the part-time student categories, a vast majority of institutions had evening classes. The highest amount of evening classes was associated with the $50-74 \%$ of part-time students. The findings also show that most institutions did not offer weekend classes. However, of those that did offer weekend classes, the highest number of institutions offering weekend classes was associated with 50-74\% part-time students at 35 institutions.

Table 4: Program Characteristics by Institution Percentages of Part-Time Students

\begin{tabular}{|c|c|c|c|c|c|c|}
\hline & \multicolumn{6}{|c|}{ Count of Institutions } \\
\hline & \multicolumn{2}{|c|}{ Size of Program } & \multicolumn{2}{|c|}{ Evening Classes } & \multicolumn{2}{|c|}{ Weekend Classe } \\
\hline & Small & Large & No & Yes & No & Yes \\
\hline 0-24\% Part-Time & 28 & 20 & 2 & 46 & 33 & 15 \\
\hline $25-49 \%$ Part-Time & 28 & 24 & 0 & 52 & 30 & 22 \\
\hline $50-74 \%$ Part-Time & 28 & 41 & 1 & 76 & 42 & 35 \\
\hline $75-100 \%$ Part-Time & 23 & 17 & 5 & 38 & 24 & 19 \\
\hline
\end{tabular}

Table 5 illustrates the graduation completion rates of the part-time groups. As previously mentioned, the graduation rates are categorized by a cohort completing the MPA program within 
three years, four years and five years. The findings show that there is an increase in part-time graduation rates as the number of years increase. As such, the highest percentage of part-time students graduating is at five years and the lowest percentage of part-time students graduating in three years. This is evidenced by the column Average Percentage of Students Graduated within 5 Years. At five years, institutions where $0-24 \%$ were enrolled part-time graduated at $83 \%, 25$ $49 \%$ part-time students graduated at $79 \%, 50-74 \%$ part-time students graduated at $75 \%$ and 75 $100 \%$ part-time students graduated at $67 \%$.

\section{Table 5: Graduation Completion Rates by Institution Percentages of Part-Time Students}

\begin{tabular}{|c|c|c|c|}
\hline & $\begin{array}{c}\text { Average Percentage of } \\
\text { Students Graduated within } \\
3 \text { Years }\end{array}$ & $\begin{array}{c}\text { Average Percentage of } \\
\text { Students Graduated within } \\
4 \text { Years }\end{array}$ & $\begin{array}{c}\text { Average Percentage of } \\
\text { Students Graduated within } \\
5 \text { Years }\end{array}$ \\
\hline 0-24\% Part-Time & $63 \%$ & $77 \%$ & $83 \%$ \\
\hline $25-49 \%$ Part-Time & $49 \%$ & $71 \%$ & $79 \%$ \\
\hline $50-74 \%$ Part-Time & $50 \%$ & $68 \%$ & $75 \%$ \\
\hline 75-100\% Part-Time & $39 \%$ & $58 \%$ & $67 \%$ \\
\hline
\end{tabular}

Table 6 displays a regression analysis for the graduation, percentage of part-time students, size of the program, the percentage of female students, the percentage of ethnic minority students, evening classes and weekend classes. Holding the graduation completion rates constant, two regression models were developed. The first model was used to assess the nature of the relationships between graduation, part-time students and the size of the program. This first model is displayed in columns 1,3 and 5. The second model was used to assess the nature of the relationships between all variables; graduation, part-time students, size of the program, gender, ethnicity, evening classes and weekend classes. This second model is displayed in columns 2, 4 and 6. The purpose of this was to verify the significance of the relationship between part-time students and graduation rates. 
The statistical significance is based on the variable's $t$ score and sig output from the regression analysis. To clarify, the $t$ score is significant if it is greater than 1.96 and less than -1.96. Secondly, the sig is significant if it is less than 0.05 . It should be noted that if the result yields statistical significance that the findings from this sample are representative of the rest of the population.

Table 6: Graduation Rates by Variable

\begin{tabular}{|c|c|c|c|c|c|c|}
\hline & \multicolumn{2}{|c|}{$\begin{array}{c}\text { Graduated within } \\
3 \text { Years }\end{array}$} & \multicolumn{2}{|c|}{$\begin{array}{c}\text { Graduated within } \\
4 \text { Years }\end{array}$} & \multicolumn{2}{|c|}{$\begin{array}{c}\text { Graduated within } \\
5 \text { Years }\end{array}$} \\
\hline & (1) & (2) & (3) & (4) & (5) & (6) \\
\hline \multirow[t]{2}{*}{$\%$ Part Time } & $-0.268 * * *$ & $-0.200 * * *$ & $-0.212 * * *$ & $-0.156^{* * *}$ & $-0.199 * * *$ & $-0.143 * * *$ \\
\hline & $(0.059)$ & $(0.059)$ & $(0.051)$ & $(0.051)$ & $(0.047)$ & $(0.047)$ \\
\hline \multirow[t]{2}{*}{ Size of Program } & $14.803 * * *$ & $16.594 * * *$ & $11.403 * * *$ & $11.142 * * *$ & $8.837 * * *$ & $7.638 * * *$ \\
\hline & $(3.086)$ & (3.116) & $(2.645)$ & $(2.663)$ & $(2.478)$ & $(2.492)$ \\
\hline \multirow[t]{2}{*}{$\%$ Female } & & -0.084 & & -0.62 & & -0.149 \\
\hline & & $(0.147)$ & & $(0.126)$ & & $(0.118)$ \\
\hline \multirow[t]{2}{*}{$\%$ Ethnic Minority } & & $-0.278 * * *$ & & $-0.236 * * *$ & & $-0.176 * * *$ \\
\hline & & $(0.070)$ & & $(0.060)$ & & $(0.56)$ \\
\hline \multirow[t]{2}{*}{ Evening Classes } & & $20.238 * * *$ & & $24.245^{* * *}$ & & $25.841 * * *$ \\
\hline & & $(7.875)$ & & $(6.731)$ & & $(6.298)$ \\
\hline \multirow[t]{2}{*}{ Weekend Classes } & & -3.596 & & 0.919 & & 2.130 \\
\hline & & (3.203) & & (2.737) & & $(2.561)$ \\
\hline R-Squared & 0.172 & 0.271 & 0.147 & 0.254 & 0.126 & 0.234 \\
\hline
\end{tabular}

Significance codes: '***' $0.01^{\prime * * \prime} 0.05^{\text {‘*’ }} 0.1$

(Standard Deviation)

\section{Graduated within 3 Years}

Column 1 expresses that as there is an increase of $1 \%$ of cohorts graduating within 3 years, there is a $-0.268 \%$ decrease in the percentage of part-time students. As indicated, this is statistically significant and therefore shows a correlation between the percentage of students graduating within 3 years and the percentage of part-time students. At the same $1 \%$ increase in 
graduation, the size of the program increases by $14 \%$, which is significant. Therefore, there is a significant positive correlation between the size of the program and the graduation completion rate. The R-Square indicates that the variables in this column account for $17 \%$ of the variance in graduation completion rates within 3 years.

Column 2 expresses that when other control variables are included, the previous findings in the percentage of part-time students has decreased while the findings of the size of the program increased. However, the results still indicate a significant negative correlation between graduation completion rates and the percentage of part-time students, and a significant positive correlation between graduation and the size of the program. Of the added control variables, there was a significant relationship between graduation completion and ethnicity and evening classes. There was a negative relationship between graduation completion and ethnicity. As graduation increased at a rate of $1 \%$, ethnicity decreased by $-0.278 \%$. As for evening classes, it had a positive relationship with graduation. The findings show that as graduation increased at a rate of $1 \%$, evening classes increased at a rate of $20 \%$. There was also a negative relationship between graduation rates and weekend classes, however, it was not statistically significant. Lastly, as stated by the R-Square, these variables define $27 \%$ of the variance in graduation completion rates within 3 years.

\section{Graduated within 4 Years}

Column 3 expresses that as there is an increase of $1 \%$ of cohorts graduating within 4 years, there is a $-0.212 \%$ decrease in the percentage of part-time students. As indicated, this is significant and therefore shows a correlation between the percentage of students graduating within 4 years and the percentage of part-time students. At the same $1 \%$ increase in graduation, the size of the program increases by $11 \%$, which is significant. Therefore, there is a correlation 
between the size of the program and the graduation completion rate. The R-Square indicates that the variables in this column account for $14 \%$ of the variance in graduation completion rates within 4 years.

Similar to the findings in Column 2, Column 4 expresses that when other control variables are included, the relationships between graduation and part-time students, the size of the program, ethnicity and evening classes are still statistically significant. The findings show that as graduation increases at $1 \%$ in graduating within 4 years, there is a $-0.156 \%$ decrease in part-time students and a $-0.236 \%$ decrease in ethnic minority students. At the same $1 \%$ increase in graduation, the size of the program increases by about $11 \%$, which is significant. There was also a significant positive relationship between graduation and evening classes, in that as graduation increased by $1 \%$, evening classes increased by $24 \%$. This column also expresses a positive change in the findings in Column 4 for weekend classes, however, it is not statistically significant. Lastly, the R-Square states that the variables in this column account for $25 \%$ of the variance in graduation completion rates within 4 years.

\section{Graduated within 5 Years}

Column 5 expresses that as there is an increase of $1 \%$ of cohorts graduating within 5 years, there is a $-0.199 \%$ decrease in the percentage of part-time students. As indicated, this is very significant and therefore shows a correlation between the percentage of students graduating within 5 years and the percentage of part-time students. At the same $1 \%$ increase in graduation, the size of the program increases by $8 \%$ which is significant. Therefore, there is a correlation between the size of the program and the graduation completion rate. This column indicates a negative relationship between graduating at 5 years and the variables percentage of part-time students, and a positive relationship between graduation and the size of the program. Lastly, the 
R-Square states that the variables in this column account for $12 \%$ of the variance in graduation completion rates within 5 years.

Column 6 expresses that when other control variables are included, the significant relationships are between graduation completion rates and the percentage of part-time students, the size of the program, ethnic minorities and evening classes. This shows that as graduation completion rates increase at $1 \%$, the percentage of part-time students decreases by -0.143 , the size of the program increases by $7 \%$, the percentage of ethnic minority students decreases by -0.176 , and the percentage of evening classes increases by $25 \%$. Lastly, the R-Square states that the variables in this column account for $23 \%$ of the variance in graduation completion rates within 5 years.

\section{Threats to Validity}

The threats of the validity of this study include the lack of other research on the subject matter, the number of years of available data, the data was self-reported and the limitation of variables to account for the variance in graduation rates. The researcher acknowledges these as limitations, however, offers these findings as a foundation for future research.

The absence of research on MPA enrollment statuses and graduation rates limited the researcher's knowledge of current trends in the program. The lack of recent literature on the graduate programs and enrollment statuses also limited the researcher's knowledge of general trends. While past research offered insight into the topic, they only accounted for trends at that point in time. As a result, there is a lack of research on the topic of graduation rates and enrollment statuses that account for current economic, personal or professional influences.

The available years of data was a longitudinal limitation because the results only described two academic years, therefore, the findings could have been situational to the years 
analyzed. Access to multiple years would have allowed the researcher to have a better understanding of the relationships in the sample, and increased the confidence in associating the correlations with the general population. Self-reported data can rarely be independently verified. Since the data was self-reported by MPA accredited institutions, the raw data had to be analyzed and assessed at face-value.

Lastly, there was a limited number of variables available to describe the variance of graduation rates in NASPAA accredited MPA programs. It would have been ideal to have additional control variables to see the influence on part-time students. This would enhance the robustness check, which enables the researcher to examine how part-time enrollment findings are affected by the addition of other factors. Additional variables or factors influencing graduation completion that would enhance the understanding of graduation rates are age, marital status, parental status, family education history, work status, income, student motivations and student satisfaction with the program and faculty. 


\begin{abstract}
ANALYSIS
The primary purpose of this study was to identify whether there was a correlation between enrollment status and graduation rates in NASPAA accredited MPA programs in the United States. The independent variable, percentage of part-time students, was used to define the enrollment status of the sample. The dependent variable, graduation completion rates, was held constant in each of the regression models. The findings show that even when other control variables were included in the regression model, there was a consistent negative significant relationship between graduation rates and the percentage of part-time students. In contrast, this negative relationship between part-time students and graduation completion rates at three years, four years, and five years show that there is a positive relationship between full-time students and graduation completion rates.
\end{abstract}

The cross tabulation in Table 5 found that the percentage of part-time students enrolled in an MPA program influences the program's graduation rates. The findings express that throughout the institutions, programs with part-time students had the highest graduation rates at the fifth year of the program. The second highest rate of degree completion among part-time students was at four years. This indicates that part-time students are more likely to need more time to complete the MPA program than just the extra time accounted for in taking fewer classes each semester. This suggests that there is also more time needed by part-time students to complete their culminating experience requirements. These findings are in line with the literature review stating that part-time students complete a graduate program at a slower rate than those of their full-time counterparts. Part-time MPA students may have external distractions, such as employment, families or financial responsibilities, that impede their program completion.

The demographic characteristics of part-time students have been shown in Table 3. It was interesting to find that institutions that had less than $49 \%$ of its students enrolled at part-time had 
a consistent $53 \%$ of female and ethnic minority students. Institutions where students were enrolled at 50-74\% part-time also had the highest percentages of female and ethnic minority students. The observation of this percentage increase lead the researcher to assume that there would be another percentage increase within the institutions where more than $75 \%$ of students were part-time. However, this group displayed a decrease in female and ethnic minority students. This research does not present a reasonable explanation for this finding.

The institution's program characteristics of part-time students were shown in Table 4. It was shown that most institutions that had less than 100 students enrolled offered evening classes, but typically did not offer weekend classes.

As stated in the literature review, academic qualities also impact graduation completion rates in master's programs. A reason for most MPA programs to have small program sizes is to promote faculty and student relationships. This, in turn, gives the student motivation and the necessary support to persist through the program. Institutions that offered evening classes displayed an awareness for their part-time students, and acknowledged potential schedule conflicts in response to employment or family obligations.

The regression analysis in Table 6 confirmed that there is a significantly negative relationship between part-time enrollment and graduation completion rates. As mentioned, this model showed that as graduation rates at 4 years increased by $1 \%$, the percentage of part-time students decreased by about one-fifth of a percent. This is considered a significant relationship between enrollment statuses and graduation rates of MPA programs. Of all the regression models conducted, the model indicated in Column 4 accounts for the most variance in graduation rates. This means that the variables in the model, percentage of part-time, size of the program, 
percentage of female, percentage of ethnic minority, evening classes and weekend classes, represented $25 \%$ of the reason why students graduated within 4 years from the MPA program.

Interestingly, the regression analysis displayed a significant positive relationship between graduation rates and the size of the program. While it was found that most MPA programs were small, the regression analysis expressed that as graduation rates increased, as did the size of the MPA program. This is in opposition to the literature review's statements that smaller graduate programs lead to students completing the program sooner than larger programs. Although this study does not provide reasoning for this anomaly, it may be in response to larger programs possessing more institutional support and resources for students to persist through the MPA program.

The findings also expressed that NASPAA accredited MPA programs in the United States have made accommodations for the characteristics of a working and commuting student. This is evidenced by the significant relationship between graduation completion rates and evening classes. This assumes that the part-time student population is likely to enroll in evening courses for the MPA program. It can further assume that these students are preoccupied with family or work obligations during the day. The findings also indicate that NASPAA accredited MPA programs have leveraged their technological advancements by promoting internet access to MPA courses. This is evidenced by schools self-reporting that they offer online MPA courses. While the findings for this control variable were not statistically significant, it is beneficial to note this innovative feature. Overall, these findings display that NASPAA accredited MPA programs acknowledge the part-time student population and are enhancing their skillsets for professional careers in public service. 


\section{CONCLUSION}

This research focuses on identifying whether there was a correlation between enrollment statuses and graduation rates in NASPAA accredited MPA programs. Raw data from the NASPAA public database was used to compile the findings of this research, which guided the analysis of the research and the subsequent conclusions. Further, the use of correlation and regression analysis adequately provided an answer to this study's research question.

Overall, the statistical significance between part-time students and graduation rates leads to the conclusion that there is a negative correlation between enrollment status and graduation rates of NASPAA accredited MPA programs. The regression analysis concludes that there is a negative correlation between part-time enrollments and graduation rates of the MPA degree program in NASPAA accredited schools. Conversely, this conclusion can assume that there is a positive correlation between full-time enrollments and graduation rates of the MPA degree program in NASPAA accredited schools.

In order to develop a better understanding of graduation rates in NASPAA accredited schools, is it advisable for NASPAA to continue to obtain data in a standardized manner. Researchers might want to enhance their findings by independently collecting demographic and social data from representative samples of MPA students at NASPAA accredited schools. These factors might include age, marital status, parental status, family education history, work status, income, students' motivation and student satisfaction. 


\section{SOURCES CONSULTED}

Blumenstyk, G. (2012). The Chronicle of Higher education. In Speech on Economy, Obama Vows to 'Shake Up' Higher Education. Retrieved from: http://www.chronicle.com/article/in-speech-on-economy-obama/140525

Brigham Young University. (2016). Effects of Employment on Student Academic Success. Retrieved from: https://www.byu.edu/hr/sites/default/files/effects_of_student_employment.pdf

Bright, L., Graham Jr., C. B. (2016) Predictors of Graduate Student Satisfaction in Public Administration Programs. Retrieved from: http://web.b.ebscohost.com.libaccess.sjlibrary.org/ehost/detail/detail?vid=0\&sid=23baa1 45-d185-4519-a62210ef23bce6ce\%40sessionmgr101\&bdata=JnNpdGU9ZWhvc3QtbG12ZSZzY29wZT1zaX $\mathrm{Rl} \# \mathrm{db}=\mathrm{ehh} \& \mathrm{AN}=113172158$

California State University. (n.d.). Glossary of Terms. Retrieved from: https://www.calstate.edu/as/stat_abstract/stat0809/pdf/z8a09.pdf

Cheng, L. (2017). NASPAA Annual Accreditation Data Report 2015-2016. Retrieved from: https://naspaaaccreditation.files.wordpress.com/2017/10/2015-16-accr-data-report2.pdf

CiviCore. (n.d.) NASPAA School Search. Retrieved from: $\mathrm{http}: / /$ naspaa.civicore.com/search/index.php?section=basic\&action=list_cycle9\&fwID $=6$ 4506

EKU. (2018). Registration Guide. Retrieved from: https://gradschool.eku.edu/registration-guide

Gardner, S. \& Gopaul, B. (2012). The Part-Time Doctoral Student Experience. Retrieved from: http://informingscience.com/ijds/Volume7/IJDSv7p063-078Gardner352.pdf

Girves, J. \& Wemmerus, V. (1988). Developing Models of Graduate Student Degree Progress. Retrieved from: http://www.jstor.org.libaccess.sjlibrary.org/stable/1981691?seq=8\#page_scan_tab_conten ts

Hegart, N. (2011). Adult Learners as Graduate Students: Underlying Motivation in Completing Graduate Programs. The Journal of Continuing Higher Education. Retrieved from: http://web.b.ebscohost.com.libaccess.sjlibrary.org/ehost/pdfviewer/pdfviewer?vid=4\&sid $=7013 \mathrm{ca} 18-63 \mathrm{~b} 7-4 \mathrm{f} 18-8 \mathrm{bd} 5-97 \mathrm{~cd} 93 \mathrm{~b} 29 \mathrm{a} 40 \% 40$ sessionmgr 103 
Hussar, W. \& Bailey. (2013). Projections of Education Statistics to 2021. Retrieved from: https://nces.ed.gov/pubs2013/2013008.pdf

Illinois Graduate School. (2018). E. Time Limits. Retrieved from: https://grad.illinois.edu/gradhandbook/2/chapter6/time-limits

Kellough, J. (2014). NASPAA in a Time of Transition. Retrieved from: http://www.jstor.org/stable/24369700?seq=1\#page_scan_tab_contents

Mullen, A., Goyette, K., \& Soares, J. (2003). Who Goes to Graduate School? Social and Academic Correlates of Educational Continuation after College. American Sociological Association. Retrieved from: http://www.jstor.org/stable/3090274?casa_token=OkCVf5qEgjYAAAAA:8etqE4mlb22 VaWR_rpOelWBJOG4TbdBcAKwpzwa414GzoZuM64a3gpw9ARTYsuJ2qPGcU911VZ yepF8eOSQCuKgKJC-3CLRtUU9B2qf8FdtiE508h-8\&seq=8\#page_scan_tab_contents

NASPAA. (n.d.). An Overview of NASPAA. Retrieved from: http://www.naspaa.org/about_naspaa/about/overview.asp

NASPAA. (2014). NASPAA Standards. Retrieved from: https://naspaaaccreditation.files.wordpress.com/2015/02/naspaa-accreditationstandards.pdf

NASPAA. (2016). NASPAA Data Center. Retrieved from: http://www.naspaa.org/DataCenter/NASPAADisaggregatereports.asp.

NASPAA. (2017). 2017-2018 Roster of Accredited Programs. Retrieved from: https://naspaaaccreditation.files.wordpress.com/2017/09/annual-roster-of-accreditedprograms-09-01-17.pdf

NASPAA. (2018a). About NASPAA Accreditation. Retrieved from: https://accreditation.naspaa.org/about/

NASPAA. (2018b). Data on Accredited Programs. Retrieved from: https://accreditation.naspaa.org/resources/data-on-accredited-programs/

NASPAA. (2018c). Historical Guidelines. Retrieved from: https://accreditation.naspaa.org/about/historical-documents/ 
NASPAA. (2018d). Standard 4: Matching Operations - Serving Students. Retrieved from: https://accreditation.naspaa.org/standard-4/

National Center for Education Statistics. (2013). Digest of Education Statistics. Average graduation tuition and required fees in degree-granting postsecondary institutions. Retrieved from: https://nces.ed.gov/programs/digest/d13/tables/dt13_330.50.asp

Naylor, L., Wooldridge, B., Lyles, A. (2014). U.S. public administration programs: Increasing academic achievement by identifying and utilizing student learning styles. Retrieved from: http://journals.sagepub.com/doi/abs/10.1177/0144739414522481

Pautz, M., \& Neeley, G. (2017). Beyond the Usual Complaints: The Front-Line Challenges and Opportunities of Small MPA Programs. Retrieved from: http://web.b.ebscohost.com.libaccess.sjlibrary.org/ehost/pdfviewer/pdfviewer?vid=1\&sid $=27650 \mathrm{~d} 27-\mathrm{c} 9 \mathrm{fb}-45 \mathrm{cc}-9997-6 \mathrm{f} 75395 \mathrm{e} 4 \mathrm{aff} \% 40$ sessionmgr104

Selingo, J. (2013). Graduation Rate: Flawed as a Measure of Colleges, but still useful. Retrieved from: https://www.chronicle.com/blogs/next/2013/05/19/graduation-rates-flawed-as-ameasure-of-colleges-but-still-useful

Sylvia, R. \& Sylvia, K. (2012). Program Planning \& Evaluation for the Public Manager, Waveland Press, ISBN 1-57766- 778-6. 2012.

The Master's Degree, 5 CCR $\S 40510$. Retrieved from: https://govt.westlaw.com/calregs/Document/IF41B2430D48211DEBC02831C6D6C108E ?contextData $=(\mathrm{sc}$. Search $) \&$ rank=1 \&originationContext=Search+Result\&navigationPath $=$ Search $\% 2 \mathrm{Fv} 3 \% 2 \mathrm{Fsearch} \% 2 \mathrm{Fresults} \% 2 \mathrm{Fnavigation} \% 2 \mathrm{Fi} 0 \mathrm{ad} 6005600000150 \mathrm{da} 221 \mathrm{fa} 74$ 7d412c2\%3FstartIndex\%3D1\%26Nav\%3DREGULATION_PUBLICVIEW\%26context Data\%3D(sc.Default)\&list=REGULATION_PUBLICVIEW\&transitionType=SearchIte $\mathrm{m} \&$ listSource $=$ Search\&viewType $=$ FullText\&t_T2 $=40510 \& \mathrm{t} \_\mathrm{S} 1=\mathrm{CA}+\mathrm{ADC}+\mathrm{s}$

Torpey, E. \& Terrel, D. (2015). Bureau of Labor Statistics. Should I get a master's degree? Retrieved from: https://www.bls.gov/careeroutlook/2015/article/should-i-get-a-mastersdegree.htm

UCONN. (2018). Bringing Students to Uconn. Retrieved from: https://grad.uconn.edu/faculty/bringing-students-to-uconn/

United States Department of Education. (n.d.). Accreditation in the United States. Retrieved from https://www2.ed.gov/admins/finaid/accred/accreditation.html\#Overview 
United States Department of Education. (2007). The Path Through Graduate School: A

Longitudinal Examination 10 Years After Bachelor's Degree. Retrieved from: https://nces.ed.gov/pubs2007/2007162.pdf

UA. (2018). Admission Criteria. Retrieved from: https://catalog.ua.edu/graduate/about/academic-policies/admission-criteria/

UO. (2018). Graduate School: Summary of Master's Degree Minimum Requirements. Retrieved from: https://gradschool.uoregon.edu/policies-procedures/masters 